\title{
Plectania protracta (Fr.) Gelin in Finland
}

\author{
Yrjö Mäkinen
}

Publications from the Department of Botany, University of Turku, No. 47

Plectania protracta, one of the most beautiful fungi, was first described under the name Peziza protracta by FrIES (1851) and transferred to the genus Plectania by Gelin (1938 a). It has also been separated into the genus Anthopeziza with a name $A$. protracta (Fr.) Nannf. After Fries, the fungus is described many times, and its synonymy is thus quite well developed; one of the commonest synonymes is Sarcoscypha protracta. For a complete list of ca. 15 synonymes, as well as the general morphology of the species, to REHM (1896), Mrgula (1913), Heim (1926), Seaver (1928), Buchwald (1941) and Omai (1938) is referred. The distribution area includes according to GELIN (1938b), ImaI (1938) and Dennis (1960) Japan, Siberia, Scotland, North and Central Europe (and North America). A southern race of a restricted area occurs in certain parts of Hungaria, Moravia and Austria. This race, described as a species under a name Anthopeziza winteri Wettst., has a slightly differing habitus and clearly smaller ascospores; it hardly deserves a status of a species as emphasized by Arwidsson (1940), but should be treated as a subspecies or variety of Plectania protracta, as GeLIN (1938 b) has made in the combination $P$. protracta var. winteri (Wettst.) Gelin.

In Scandinavia, Gelin (1938 a) cites 8 localities from Sweden, 4 from Norway and 1 from Finland. In Denmark the species is apparently not found (Buahwald 1941, Ferdinandsen \& Wrnge 1943). Later two new localities in Sweden have been found, one in Ångermanland (Sollefteå; LUNDELL \& NANNFELDT $1946 \mathrm{~N}$ :o 1359) and one in Uppland (Sigtuna; SöDERBERG 1949, 1950). The northernmost localities known are in Sweden in Torne Lappmark and in Norway in Troms. The only Finnish locality known is in South Häme, Mustiala, where $P$. protracta was first collected in 1869 by P. A. Karsten (KarsteN 1871 p. 44) and later in 1887 and 1889 by R. Gripenberg $(\mathrm{H})$. Three more localities are now known.
1) H. Snellman has collected the species 13.6.1949 in North Ostrobothnia ( $\gg \mathrm{Kemi}$, Karihaara, in grass in a garden on decomposing wood and roots», n. lat. $\left.65^{\circ} 45^{\prime} ; \mathrm{H}\right)$.

2) 21.5.1955 I found the species in VarsinaisSuomi, Kuusisto commune, in the western part of the island Jauhosaari (n. lat. $60^{\circ} 23^{\prime}$ ). Only one fruiting body grew near the northern shore on a moist slope covered by spruce and Paris quadrifolia as an undergrowth; the bottom layer was dominated by two mosses, Rhytidiadelphus triquetrus and Hylocomium splendens with Cirriphyllum piliferum in open places. This part of the island has a very rich vegetation including many basocline species (MÄKINEN \& TARÉN 1961).

3) In the spring 1961 many localities were found in Finnish Lapland, Utsjoki commune, around the lake Kevojärvi near the Kevo Subarctic Research Station (n. lat. $69^{\circ} 45^{\prime}$ ); these are thus the northernmost localities of this species:

a) $26.5 \mathrm{my}$ wife and I found Plectania near the mouth of the R. Tsharsjoki, on the shore of the lake Kevojärvi. The locality was a sandy meadow, which had been inundated for some days after the break- up of the ice. At this time even the earliest vasculars in the vicinity were not yet in the flower; Luzula pilosa and Carex vaginata were in the bud and Thalictrum minus v. rolundifolium and Trollius europaeus had developed shoots of $15 \mathrm{~cm}$ length, while grasses like Roegneria canina, R. mutabilis and Calamagrostis purpurea, which later appeared on this place, had not yet started their growth. In all we counted 8 fruiting bodies in an area of 1 sq. meter.

b) Some days later, 29.5, we walked along the R. Tsharsjoki and found the species again on a moist sandy bottom of a small inundation bed. After a search of a few hours we could state that the species was rather common on that ca. $500 \mathrm{~m}$ long and 


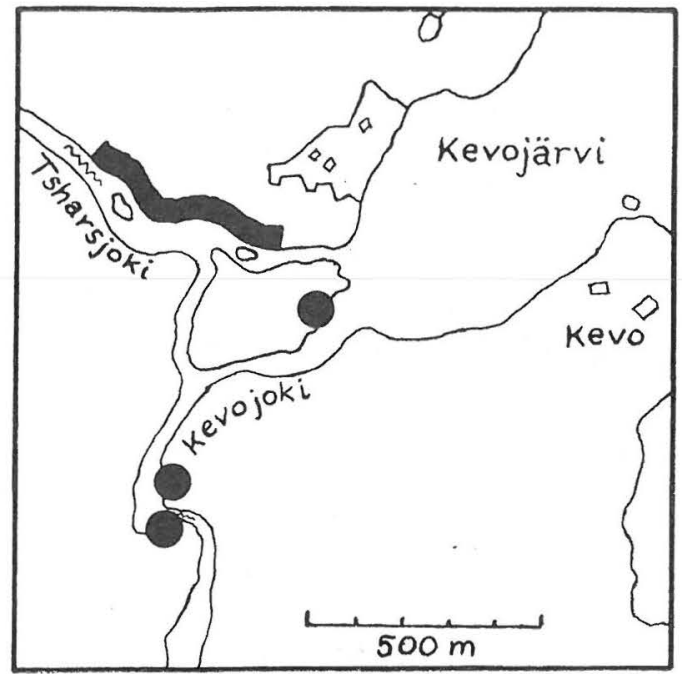

Fig. 1. The localities for Plectania protracta in Finnish Lapland.

$30-40 \mathrm{~m}$ broad area along the river that we examined. Nowhere it was abundant; usually only 5-10 fruiting bodies were seen at one place, and these had developed from the branches of the same mycelium. All the places were rather similar: moist shrubbery (Salix glauca, S. lapponum, S. phylicifolia, $S$. hastata), which had been inundated for some days about 1 week earlier. The sandy bottom of these inundation beds was almost free from vegetation.

c) On June 2, I found three fruiting bodies on a sandy shore of the R. Kevojoki between the cliff
Kotkapahta and the mouth of the river. Plectania grew about $20 \mathrm{cms}$ from the water line, together with Equisetum variegatum, Salix hastata and Astragalus alpinus.

d) On June 18, Mr. Atte Vuoristo found the fungus also on the shore of the R. Kevojoki, near to the previous locality, on a steep bank about 120 cms above the water level, in a moist moss cover dominated by Pleurozium schreberi. It thus appears, as if the species were not rare in suitable places, but has been overlooked because of its early appearance. Fig. 1 shows the map of the recorded Lappish localities.

Plectania protracta has a long creeping and branched rhizomlike dark mycelium, which develops several fruiting bodies; these are often found in the same place during several years. They appear early in the spring, usually already in May; their foot is $1-2 \mathrm{~cm}$ long, and the apothecium is in the beginning bellshaped with a small hole (Fig. 2 a), but opens in ripening and splits into 6-12 lobes (Fig. 2 b); Moesz (1942 p. 101) has a good picture of the var. winteri. The red colour of the apothecium is due to the red oil drops in the paraphyses. The ascospores (Fig. 2 c) are very typical for this species, thickwalled and seemingly $2-4$ celled, due to the big oil drops that occupy most of the spore. Measurements of 100 spores from the Tsharsjoki locality gave the length of $36-54 \mu$ with a mean of $43.9 \pm 0.4 \mu$ and the breadth of $12-20 \mu$, mean $15.0 \pm 0.2 \mu$. The asci were $250-400 \mu$ long and $18-20 \mu$ thick.

During the spring this fungus certainly deserves more attention to clarify its distribution in Finland.
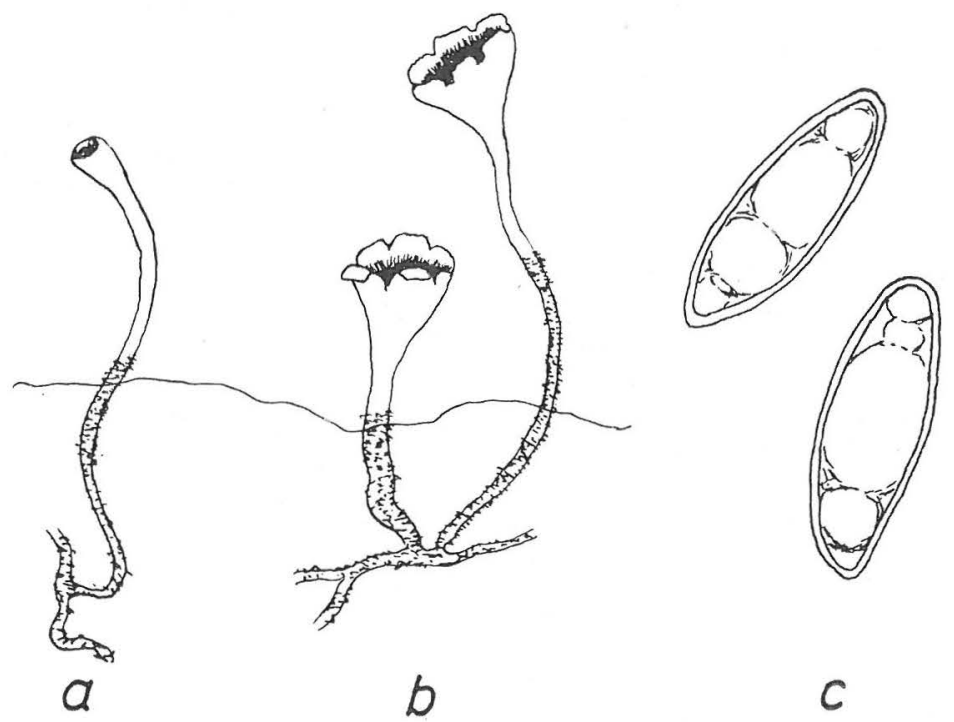

Fig. 2. a) young, b) mature specimen of Plectania protracta $(1.5 \times)$; c) two ascospores, showing the thick wall and the big oil drops $(700 \times)$. 


\section{LITERATURE GITED}

Arvidsson, T., 1940: Mykologische Beiträge. Bot. Not. 1940, 370-388.

Buchwald, F., 1941: Om Plectania protracta (Fr.) Gelin og P. coccinea (Fr.) Fckl. i Danmark. - Friesia 2:2-3, 166 -171 .

Dennis, R. W. G. 1960: British Cup Fungi and Their Allies. - The Ray Society, London. 280 pp.

Ferdinandsen, C. \& Winge, Ø., 1943. Mykologisk Ekskursionsflora. 2. ed., 428 pp. - København.

Fries, E., 1851: Novarum symbolarum mycologicarum mantissa. - Acta Reg. Soc. Sci. Ups. 3:1, 225-231.

Gelin, O., 1938 a: The distribution in Scandinavia of Plectania protracta(Fries) Gelin, comb. nov. and Plectania coccinea (Scop.) Fuckel. - Kgl. Norske Vidensk. Selsk. Forh. 10:52, 194-197.

$\longrightarrow$ $1938 \mathrm{~b}$ : Variation in the length of the ascospores in Plectania protracta (Fr.) Gelin and Plectania coccinea (Scop.) Fuckel. - Ann. Agric. Coll. Sweden (Lantbrukshögskolans Annaler) 7, 41- 49 .

Heim, R., 1926: Fungi Brigantiani. - Bull. Soc. Mycol. France 41, 451-457 (not seen).

ImAI, S, 1938: Symbolae ad Floram Mycologicam Asiae Orientalis. II. - Bot. Mag. $52,357-363$.
Karsten, P. A., 1871 : Mycologia Fennica. I. Discomycetes. - Bidr. känned. Finl. Nat. Folk 9, 1-263.

Lundell, S. \& Nannfeldt, J. A., 1946: Fungi Exsiccati Suecici, praesertim Upsalienses, Fasc. XXVII-XXVIII (Nr. 1301-1400).

Migula, W., 1913: Ascomycetes: Dothideales, Hypocreales, Hysteriales, Discomycetes, Laboulbeniaceac. - Kryptogamen-Flora von Deutschland, Deutsch-Österreich und der Schweiz, III : 3, 2 .

Moesz, G., 1942: Die Pilze von Budapest und seiner Umgebung. 319 pp. Budapest.

MÄkinen, Y. \& TARÉn, N., 1961: Piikkiön Harvaluodon ja Jauhosaaren kasvistosta. - Turun Ylioppilas VII, 93-128.

Reнm, H., 1896. Ascomyceten: Hysteriaceen und Discomyceten. - Rabenhorst's Kryptogamen-Flora, 2. ed., I:III.

Seaver, F.J., 1928: The North American Cupfungi (Operculates). - New York.

SöderberG, S., 1949: Ett par disksvampfynd våren 1949. - Bot. Not. 1949, 161-162. $\longrightarrow$ 1950: Bidrag till Bergianska trädgårdens svampflora jämte nảgra andra svampfynd från Stockholmstrakten 1950. - Sv. Bot. Tidskr. 44 : 4, 562-563. 